\title{
The effect of hydroalcoholic extract of Crataegus monogyna on hyperglycemia, oxidative stress and pancreatic tissue damage in streptozotocin-induced diabetic rats
}

\author{
Saeid Valipour Chahardahcharic ${ }^{1}$, Mahbubeh Setorki $^{1 *}$ \\ ${ }^{1}$ Department of Biology, Izeh Branch, Islamic Azad University, Izeh, Iran
}

\section{A R T I C L E I N F O}

Article Type:

Original Article

\section{Article History:}

Received: 7 April 2018

Accepted: 10 September 2018

\section{Keywords:}

Crataegus monogyna

Diabetes mellitus

Stress oxidative

Rat

\begin{abstract}
A B S T R A C T
Introduction: Diabetes mellitus is one of the most common metabolic diseases that causes damage to different tissues through oxidative stress. The aim of this study was to evaluate the effect of hydroalcoholic extract of Crataegus monogyna on oxidative stress, hyperglycemia and pancreatic tissue damage in diabetic rats.

Methods: In this experimental study, 40 male Wistar rats were equally divided into 5 groups including control (normal saline), diabetic control (streptozotocin), intervention (streptozotocin plus C. monogyna extract at doses of 100, 200 and $400 \mathrm{mg} / \mathrm{kg}$ ). After treatment, serum levels of malondialdehyde (MDA), Ferric reducing ability of plasma (FRAP) and glucose were determined. Histological sections of the pancreas were also prepared for histological examination.

Results: Treatment of diabetic rats with C. monogyna extract significantly reduced blood glucose level $(P<0.05)$. Compared with control group MDA was increased and TCA was decreased in diabetic rats $(P<0.05)$. Treatment of diabetic rats with $C$. monogyna extract significantly increased TCA and reduced MDA $(P<0.05)$. In the pancreas of diabetic rats, degeneration of pancreatic acinar cells and formation of dermato space, damage of lobules and Acinii and edema were observed and treatment with C. monogyna extract ameliorated them.

Conclusion: The results confirm the role of C. monogyna extract in the treatment of hyperglycemia, stress oxidative indices and pancreatic tissue damage in diabetic rats. Therefore, it might be beneficial in diabetic patients.
\end{abstract}

Implication for health policy/practice/research/medical education:

The results confirm the role of $C$. monogyna extract in treatment of hyperglycemia, oxidative stress indices and pancreatic tissue damage in diabetic rats. Therefore, it might be beneficial in diabetic patients.

Please cite this paper as: Valipour Chahardahcharic S, Setorki M. The effect of hydroalcoholic extract of Crataegus monogyna on hyperglycemia, oxidative stress and pancreatic tissue damage in streptozotocin-induced diabetic rats. J Herbmed Pharmacol. 2018;7(4):294-299. doi: 10.15171/jhp.2018.44.

\section{Introduction}

One of the most common diseases of the body's endocrine system is diabetes, which prevalence is increasing in human societies. There are two main types of diabetes. In type I diabetes, the degradation of beta cells in the pancreas leads to defective insulin production. In type II diabetes, there is a progressive body's resistance to insulin, which may ultimately lead to the destruction of pancreatic beta cells and the complete defect in the synthesis of insulin (1). In type II diabetes, which account for 90\%-95\% of diabetic cases, genetic factors, obesity, and dementia play important roles in developing the disease (2). It is estimated that more than $3.6 \%$ of the world's population currently have diabetes mellitus (3). Diabetes mellitus is characterized with symptoms such as hyperglycemia, polyuria, polydipsia, polyphagia, and the appearance of glucose in the urine. In long terms, it will be associated with serious and irreversible complications such as retinopathy, nephropathy, neuropathy, and vascular injuries (4). In diabetes mellitus, the oxidative stress caused by chronic hyperglycaemia plays a major role in the progression of the disease and the appearance of related symptoms. The oxidative stress in the cells and tissues originates from the increased production of reactive oxygen species (ROS) or the reduced potential for antioxidant defense (5). Several hypotheses have been introduced to explain the increase 
in the ROS production during diabetes, including glucose autoxidation, non-enzymatic and progressive glycosylation of proteins, increased ultimate glycemic products and the polyol metabolism pathway. The formation of free radicals causes the destruction of cells vital macromolecules, peroxidation of membrane lipids, and ultimately the cell damage (4). Streptozotocin (STZ) is an antibiotic produced by Streptomyces achromogenes, and is usually used to induce diabetes in the experimental models. Hyperglycemia and oxidative stress play an important role in the etiology and pathology of STZ-induced complications (6). Through increasing the production of free radicals and ROS, STZ causes the DNA cleavage and methylation in the pancreatic beta cells (7). The STZ also discharges nicotinamide adenine dinucleotide (NAD) in the insulin-making cells of the Islets of Langerhans (8). Due to the role of oxidative stress in the pathogenesis and etiology of diabetes, the researchers have nowadays focused on the use of compounds with antioxidant activity and the potential of free radicals removal to prevent the damage and degeneration of the pancreatic beta cells in the diabetic models (6).

Nowadays, the researchers' attention has focused on the use of natural compounds with multiple antioxidant, antiinflammatory, anti-hyperlipidemia, and hepatoprotective activities for the management of diabetes-related disorders (10). Common hawthorn (Crataegus monogyna) is the name of a species of Hawthorn (Crataegus) species. It is a native ornamental herb of Europe, North-West Africa and West Asia and is an invasive species (11). Common hawthorn has dark red small fruits called haw, which ripen in the mid-autumn and are used for medical purposes and also as a condiment in some foods like jellies, jams, and syrups (12). Scientific evidence has shown that the common hawthorn fruit has anti-oxidant and strong inhibiting activity on free radicals due to the presence of various bioactive compounds such as epicatechin, hyperoside, quercetin, vitexin, coumarin, and chlorogenic acid (12,13). These compounds have numerous pharmacological neuroprotective, hepatoprotective, and cardioprotective effects $(10,12)$. In addition, the common hawthorn fruit has tonic effects on the heart (12). Several studies have shown that the common hawthorn can reduce some cardiovascular risk factors such as high blood pressure, hypocholesterolemia, and hyperlipidemia $(14,15)$. Thus, the aim of this study was to evaluate the effect of hydro-alcoholic extract of common hawthorn on hyperglycemia and oxidative stress in streptozotocininduced diabetic rats.

\section{Material and Methods \\ Extraction \\ The common hawthorn plant was purchased from an authentic attar. After scientific and systematic confirmation, $1 \mathrm{~kg}$ of dried fruit without kernel was powdered and placed into a beaker. Subsequently, an}

adequate amount of $70 \%$ methanol solution was added to completely cover the powdered particles. Then, it was placed on a shaker for 2 days at room temperature. The resulting mixture was filtered and the solvent was separated by a rotary. The resulted extract was then dried completely at $37^{\circ} \mathrm{C}$ in the incubator and used for the preparation of the required concentrations. The extract was stored in the freezer $-20^{\circ} \mathrm{C}(16)$.

\section{Laboratory animals}

The tested animals were male Wistar rats weighing 250$300 \mathrm{~g}$. The animals were kept in appropriate temperature conditions $\left(22 \pm 2^{\circ} \mathrm{C}\right)$ under 12 hours of light (from 8 to 20 ) and 12 hours of dark with free access to similar water and food at the animal nest of Islamic Azad University, Izeh Branch. The tests on animals were done based on the Ethics of Working with laboratory animals approved by the Ethics Committee at the Deputy of Research and Technology of Islamic Azad University. To perform the study, we used the rats that their serum glucose levels were less than $130 \mathrm{mg} / \mathrm{dL}$ in normal and fasting conditions (17). To do the test, a drop of blood was taken from the rat's tail and the blood glucose levels were determined using a glucometer device. To induce diabetes in the rats, the STZ was administered as $60 \mathrm{mg} / \mathrm{kg}$ single dose intraperitoneally as solution in the physiologic cold saline. Following 72 hours of the STZ injection and after observing the symptoms of diabetes (increased blood glucose levels to more than $250 \mathrm{mg} / \mathrm{dL}$ and polydipsia) (17), the treatment with the extract was done for 3 weeks daily and intraperitoneally. The rats were divided into five groups $(n=8)$. The control group included healthy rats that received normal saline as intraperitoneal injection for 3 weeks. The negative control group included untreated diabetic rats that received normal saline for 3 weeks. The treated diabetic groups received the common hawthorn extract at doses of 100,200, and $400 \mathrm{mg} / \mathrm{kg}$ for 3 weeks $(18,19)$. After 3 weeks, the rats were kept for 12 hours in a fasting condition. They were then anaesthetized by chloroform and blood samples were taken from their hearts. The serum was isolated from the blood samples by centrifugation and transferred to the laboratory for performing biochemical tests (20). The pancreatic tissue was also prepared for histological examination.

\section{Serum glucose measurement}

At the end of the study, the samples were transferred to the laboratory. The serum specimens were separated from the blood samples. Then, using the commercial kits of Pars Azmoon Company (Tehran, Iran) and an Autoanalyzer (Biotecnica BT-3000), the blood glucose levels were determined.

\section{Malondialdehyde measurement}

A volume of $100 \mu \mathrm{L}$ of the serum sample and $1.5 \mathrm{~mL}$ of $20 \%$ acetic acid were added to the test tubes with $1.5 \mathrm{~mL}$ 
of $0.8 \%$ thiobarbituric acid (TBA), $200 \mathrm{uL}$ of $8.1 \%$ sodium dodecyl sulfate (SDS) and $700 \mu \mathrm{L}$ of distilled water. The tubes were placed in a boiling water bath for $60 \mathrm{~min}$. Then, $1 \mathrm{~mL}$ of distilled water and $5 \mathrm{ml}$ of butanol/pyridine were added to the specimens, which were then centrifuged and the light absorbance rates of the supernatants were measured at $532 \mathrm{~nm}(21)$.

\section{Ferric reducing ability of plasma}

The ferric reducing ability of plasma (FRAP) method was used to measure the antioxidant capacity of the serum. The FRAP work solution was prepared by using $10 \mathrm{ml}$ of acetate buffer $(0.25 \mathrm{M})(\mathrm{pH}=3.6), 5 \mathrm{ml}$ of $10 \mathrm{mM}$ TPTZ (prepared in the $40 \mathrm{mM} \mathrm{HCl}$ ) and $2.5 \mathrm{~mL}$ of $20 \mathrm{mM}$ of $\mathrm{FeCl}_{3}\left(6 \mathrm{H}_{2} \mathrm{O}\right)$. Then, $25 \mu \mathrm{L}$ of the serum sample was mixed with $1.5 \mathrm{ml}$ of the FRAP solution and placed at $37^{\circ} \mathrm{C}$ for 10 minutes. Subsequently, the optical absorption was recorded at a wavelength of $593 \mathrm{~nm}$ (21).

\section{Histological studies}

The pancreatic tissue of rats was fixed in the $10 \%$ buffered formalin solution and paraffin embedded. The 3-5 $\mu \mathrm{m}$ sections were placed on glass slides, which paraffin was removed and watered again. The slides were stained with hematoxylin and eosin $(\mathrm{E} \& \mathrm{H})$ for microscopic examination (22).

\section{Statistical analysis}

The resulting data were analyzed by SPSS software version 21. Considering that the obtained results were quantitative, the assumption of normal distribution of the frequency of data was confirmed by the Kolmogorov-Smirnov nonparametric test $(P>0.05)$. The data were also analyzed by one-way ANOVA and the post hoc least significant difference (LSD) tests. Also, the results obtained were reported together with the corresponding statistical calculations as mean \pm SEM. In all cases, the difference between groups was considered significant with $P<0.05$.

\section{Results}

The results of blood glucose levels in the experimental groups are shown in Figure 1. According to the results, the mean blood glucose levels in the STZ-receiving rats showed a significant increase compared with the control group. In addition, the treatment with doses of 100, 200, and $400 \mathrm{mg} / \mathrm{kg}$ of the common hawthorn extract caused a significant decrease of the mean values compared to the diabetic group.

The serum FRAP decreased significantly in the untreated diabetic rats compared to the control group rats $(P<$ $0.001)$ and treatment with doses of 100,200 , and $400 \mathrm{mg} /$ $\mathrm{kg}$ of common hawthorn extract $(P<0.001)$ significantly increased the FRAP levels compared to the diabetic group (Figure 2). The administration of STZ to rats significantly increased the serum MDA levels $(P<0.001)$

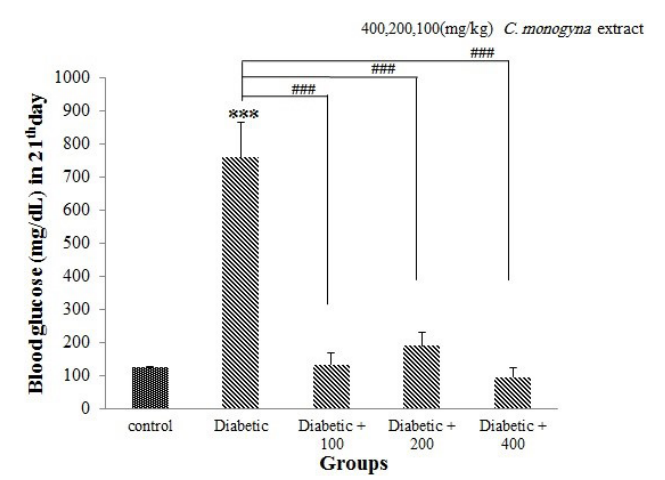

Figure 1. Comparison (mean \pm SEM) of blood glucose levels in the control, diabetic, diabetic treated with different doses of common hawthorn extract (Sign * indicates a significant difference with the control group $(P<0.001)$, sign \# represents a significant difference with the diabetic group $(P<0.001$ and $P<0.05)$.

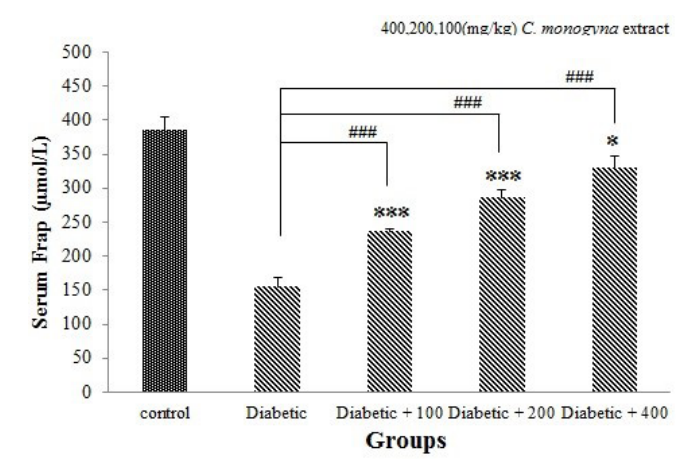

Figure 2 Comparison (mean \pm SEM) of FRAP levels in the control, diabetic, diabetic treated with different doses of common hawthorn extract (Sign * indicates a significant difference with the control group $(P<0.001)$, sign \# represents a significant difference with the diabetic group $(P<0.001$ and $P<0.05)$

and treatment with doses of 100,200 , and $400 \mathrm{mg} / \mathrm{kg}$ of common hawthorn extract significantly decreased the MDA levels compared to the diabetic group $(P<0.001$, $P<0.05$, Figure 3).

The results of histological studies of the rats' pancreas are shown in Figure 4. In the rats of the control group, the acinar cells had a normal appearance and no necrosis or degenerative changes were observed. In the pancreas of untreated diabetic rats, the degeneration of Acini and the creation of dermatome space, the brittleness of the lobules and the Acini, and edema were observed. The histological examination of the pancreatic tissue in the diabetic rats treated with common hawthorn extract at a dose of 100 $\mathrm{mg} / \mathrm{kg}$ indicated the health of the acini cells and the lobules and there were no other pathologic changes except for a brief hyperemia. In the diabetic groups treated with common hawthorn extract at doses of 200 and $400 \mathrm{mg} / \mathrm{kg}$, the Acini had a normal appearance and no necrosis and degenerative changes were seen (Figure 4).

\section{Discussion}

In this study, which was performed to examine the effect 


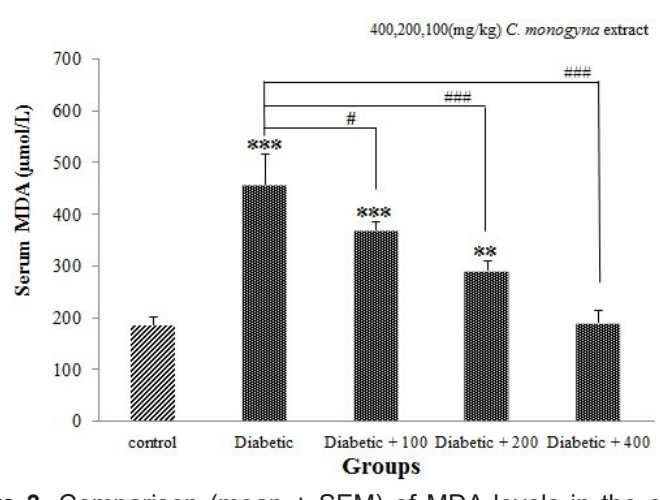

Figure 3. Comparison (mean \pm SEM) of MDA levels in the control, diabetic, diabetic treated with different doses of common hawthorn extract (Sign * indicates a significant difference with the control group $(P<0.001)$, sign \# represents a significant difference with the diabetic group $(P<0.001$ and $P<0.05)$.
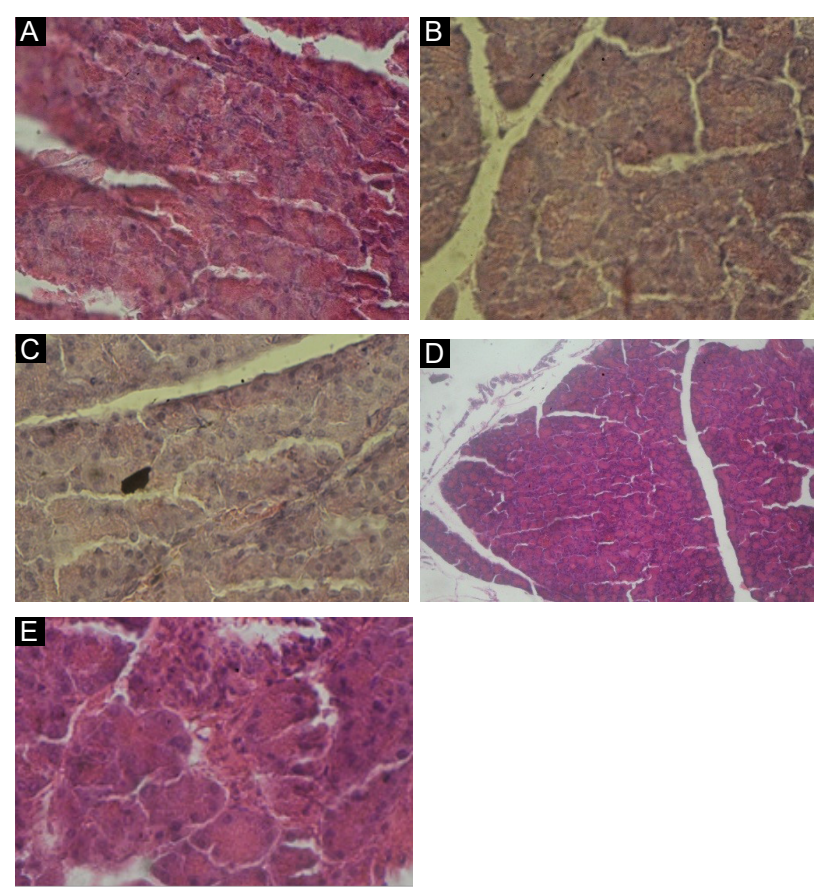

Figure 4. Pancreatic tissue sections of the control group (A), diabetic (B), diabetic recipient of a dose of $100 \mathrm{mg} / \mathrm{kg}$ of common hawthorn extract (C), diabetic recipient of $200 \mathrm{mg} / \mathrm{kg}$ of common hawthorn extract (D), and the diabetic recipient of $400 \mathrm{mg} / \mathrm{kg}$ of common hawthorn extract (E). (H\&E staining); x40 magnification.

of common hawthorn extract on hyperglycemia, oxidative stress, and pancreatic tissue damage in the STZ-diabetic rats, administration of STZ resulted in a significant increase in the serum glucose and malondialdehyde levels and a significant reduction in the serum antioxidant capacity. Consistent with the results of this study, hyperglycemia and the increased lipid peroxidation in the serum, liver, kidney, and pancreas have been reported in a number of studies following the treatment of rats with STZ $(6,16)$. In other studies, the decreased activity of antioxidant enzymes and reduced levels of endogenous antioxidants have been reported in STZ-induced diabetic rats (6).
STZ is widely used to induce experimental diabetes in the animal models (6). STZ is removed by betapancreatic cells via GLUT2 receptors, through which, enters these cells and causes tissue damage (4). The mechanism by which STZ leads to diabetes is not well known. However, it is believed that active oxygen species, including hydroxyl radicals play an important role in causing STZ-induced cell injury (7). STZ is an unstable molecule that accumulates in the pancreatic beta cells and its decomposition produces carbonium radicals. The carbonium radicals are highly reactive and cause direct or indirect toxic effects on the endothelium of the islets of Langerhans with increasing ROS production (23), leading to DNA fragmentation and DNA methylation of the pancreatic beta cells $(24,25)$. It is also found that STZ causes inflammation through infiltration of mononuclear cells in the islets of Langerhans and ultimately damage the beta cells of the pancreas (26). In addition, studies have shown that nitric oxide (NO) produced by STZ plays a major role in causing damage to the beta cells in the pancreas (27). The increased serum nitric oxide is seen in the STZ-exposed rats (6) and the use of inducing nitric oxide synthase enzyme inhibitors (iNOS), like the LNGmono-methyl arginine (NMMA) and aminoguanidine, decreases hyperglycemia and prevents the destruction of the Langerhans islets by STZ $(28,29)$. It has also been observed that the oxidative destruction of DNA caused by STZ in the islets of Langerhans is decreased by NMMA and nicotinamide (30). In the present study, the increased serum MDA as the lipid peroxidation index and pancreatic tissue damage in diabetic rats confirmed the damage caused by STZ and the resulting free radicals.

In the present study, we observed that the treatment of STZ-receiving rats by different doses of common hawthorn extract significantly decreased the blood glucose levels and improved the tissue damage of the pancreas. The common hawthorn extract also increased the serum antioxidant capacity and reduced the levels of MDA. Therefore, one can state that the common hawthorn extract represents protective effects against hyperglycemia and tissue damage of the pancreas in the diabetic rats due to antioxidant activity and reducing lipid peroxidation. Based on the studies done in the laboratory environment, the common hawthorn extract indicates a high antioxidant activity in inhibiting hydroxyl and superoxide free radicals (31-33). In hypercholesterolemic rats, the common hawthorn extract has reduced the lipids peroxidation and increased the antioxidant capacity (34). The antioxidant activity of the common hawthorn extract has been attributed to the presence of various bioactive compounds such as epicatechin, hyperoside, quercetin, vitexin, coumarin, and chlorogenic acid $(12,13)$. One study found that quercetin reduces peroxidation of lipids, forms $\mathrm{NO}$, and increases the activity of antioxidant enzymes in the STZ-induced diabetic rats. The researchers concluded that quercetin protects the pancreatic beta cells against 
STZ's destructive effects by reducing the oxidative stress parameters (6). Coumarin has also shown protective effects against hyperglycemia and the tissue damage in the liver (35). In addition, epicatechin has increased the activity of antioxidant enzymes and decreased the peroxidation of lipids in the STZ-induced diabetic rats (36). These results are consistent with the results of this study.

\section{Conclusion}

The results of this study showed that the doses of common hawthorn extract used in the diabetic rats reduce the blood glucose levels and prevent the pancreatic tissue damage, which seem to be due to the strengthening of the antioxidant defense and the reduction of lipids peroxidation.

\section{Acknowledgments}

This article is a result of the research results in the Department of Biology at Islamic Azad University, Izeh Branch. Hereby, the authors of the article would like to appreciate the Deputy of Research and Technology of Islamic Azad University, Izeh Branch for providing the proper laboratory conditions to perform this research project.

\section{Authors' contributions}

MS: Statistical analysis, data interpretation, manuscript preparation. SVC: Data collection, design of the study, literature search, funding collection. The authors read and confirmed publication of the manuscript.

\section{Conflict of interest}

The authors declare that there is no Conflict of interest.

\section{Ethical considerations}

The protocol was approved by the Vice-Chancellor of Islamic Azad University. The ethical issues (including plagiarism, misbehavior, data provision, forgery, duplicate release or submission, redundancy) were fully observed by the authors.

\section{Funding/Support}

This research was financially supported by Azad University of Izeh, Iran.

\section{References}

1. Classification and diagnosis of diabetes mellitus and other categories of glucose intolerance. National Diabetes Data Group. Diabetes. 1979;28(12):1039-57.

2. Colditz GA, Willett WC, Rotnitzky A, Manson JE. Weight gain as a risk factor for clinical diabetes mellitus in women. Ann Intern Med. 1995;122(7):481-6.

3. King H, Rewers M. Global estimates for prevalence of diabetes mellitus and impaired glucose tolerance in adults. WHO Ad Hoc Diabetes Reporting Group. Diabetes Care. 1993;16(1):157-77.
4. Eleazu CO, Eleazu KC, Chukwuma S, Essien UN. Review of the mechanism of cell death resulting from streptozotocin challenge in experimental animals, its practical use and potential risk to humans. J Diabetes Metab Disord. 2013;12(1):60. doi: 10.1186/2251-6581-12-60.

5. Baynes JW. Role of oxidative stress in development of complications in diabetes. Diabetes. 1991;40(4):405-12.

6. Coskun O, Kanter M, Korkmaz A, Oter S. Quercetin, a flavonoid antioxidant, prevents and protects streptozotocininduced oxidative stress and beta-cell damage in rat pancreas. Pharmacol Res. 2005;51(2):117-23. doi: 10.1016/j. phrs.2004.06.002.

7. Szkudelski T. The mechanism of alloxan and streptozotocin action in B cells of the rat pancreas. Physiol Res. 2001;50(6):537-46.

8. Schein PS, Cooney DA, McMenamin MG, Anderson T. Streptozotocin diabetes--further studies on the mechanism of depression of nicotinamide adenine dinucleotide concentrations in mouse pancreatic islets and liver. Biochem Pharmacol. 1973;22(20):2625-31.

9. Nasri H, Rafieian-Kopaei M. Protective effects of herbal antioxidants on diabetic kidney disease. Journal of Research in Medical Sciences. 2014;19(1):82-3.

10. Kirakosyan A, Seymour E, Kaufman PB, Warber S, Bolling S, Chang SC. Antioxidant capacity of polyphenolic extracts from leaves of Crataegus laevigata and Crataegus monogyna (Hawthorn) subjected to drought and cold stress. J Agric Food Chem. 2003;51(14):3973-6. doi: 10.1021/jf030096r.

11. Sallabanks R. Fruit fate, frugivory, and fruit characteristics: a study of the hawthorn, Crataegus monogyna (Rosaceae). Oecologia. 1992;91(2):296-304. doi: 10.1007/bf00317800.

12. Barros L, Carvalho AM, Ferreira IC. Comparing the composition and bioactivity of Crataegus monogyna flowers and fruits used in folk medicine. Phytochem Anal. 2011;22(2):181-8. doi: 10.1002/pca.1267.

13. Bahorun T, Aumjaud E, Ramphul H, Rycha M, LuximonRamma A, Trotin F, et al. Phenolic constituents and antioxidant capacities of Crataegus monogyna (Hawthorn) callus extracts. Nahrung. 2003;47(3):191-8. doi: 10.1002/ food.200390045.

14. Chang WT, Dao J, Shao ZH. Hawthorn: potential roles in cardiovascular disease. Am J Chin Med. 2005;33(1):1-10. doi: 10.1142/s0192415x05002606.

15. Salehi S, Long SR, Proteau PJ, Filtz TM. Hawthorn (Crataegus monogyna Jacq.) extract exhibits atropinesensitive activity in a cultured cardiomyocyte assay. J Nat Med. 2009;63(1):1-8. doi: 10.1007/s11418-008-0278-4.

16. Sowndhararajan K, Kang SC. Free radical scavenging activity from different extracts of leaves of Bauhinia vahlii Wight \& Arn. Saudi J Biol Sci. 2013;20(4):319-25. doi: 10.1016/j.sjbs.2012.12.005.

17. Nayak SB, Pereira PL, Maharaj D. Wound healing activity of Carica papaya L. in experimentally induced diabetic rats. Indeian Journal of Experimental Biology. 2007;45 (8):739743.

18. Chowdhury SS, Islam MN, Jung HA, Choi JS. In vitro antidiabetic potential of the fruits of Crataegus pinnatifida. Res Pharm Sci. 2014;9(1):11-22.

19. Shalizar Jalali A, Hasanzadeh S. Crataegus monogyna fruit aqueous extract as a protective agent against doxorubicin- 
induced reproductive toxicity in male rats. Avicenna J Phytomed. 2013;3(2):159-70.

20. Srivastava A, Shivanandappa T. Hepatoprotective effect of the root extract of Decalepis hamiltonii against carbon tetrachloride-induced oxidative stress in rats. Food Chem. 2010;118(2):411-7. doi: 10.1016/j.foodchem.2009.05.014.

21. Zahedi M, Hojjati MR, Fathpour H, Rabiei Z, Alibabaei Z, Basim A. Effect of Rheum Ribes Hydro-Alcoholic Extract on Memory Impairments in Rat Model of Alzheimer's Disease. Iran J Pharm Res. 2015;14(4):1197-206.

22. Ashraf H, Zare S, Farnad N. The effect of aqueous extract of barberry fruit on liver damage in streptozotocin - induced diabetic rats. J Shahrekord Univ Med Sci. 2014;15(6):1-9.

23. Jang YY, Song JH, Shin YK, Han ES, Lee CS. Protective effect of boldine on oxidative mitochondrial damage in streptozotocin-induced diabetic rats. Pharmacol Res. 2000;42(4):361-71. doi: 10.1006/phrs.2000.0705.

24. Yamamoto H, Uchigata $Y$, Okamoto H. Streptozotocin and alloxan induce DNA strand breaks and poly(ADP-ribose) synthetase in pancreatic islets. Nature. 1981;294(5838):2846.

25. Takasu N, Komiya I, Asawa T, Nagasawa Y, Yamada T. Streptozocin- and alloxan-induced $\mathrm{H} 2 \mathrm{O} 2$ generation and DNA fragmentation in pancreatic islets. $\mathrm{H} 2 \mathrm{O} 2$ as mediator for DNA fragmentation. Diabetes. 1991;40(9):1141-5.

26. Like AA, Rossini AA. Streptozotocin-induced pancreatic insulitis: new model of diabetes mellitus. Science. 1976;193(4251):415-7.

27. Kaneto H, Fujii J, Seo HG, Suzuki K, Matsuoka T, Nakamura $\mathrm{M}$, et al. Apoptotic cell death triggered by nitric oxide in pancreatic beta-cells. Diabetes. 1995;44(7):733-8.

28. Lukic ML, Stosic-Grujicic S, Ostojic N, Chan WL, Liew FY. Inhibition of nitric oxide generation affects the induction of diabetes by streptozocin in mice. Biochem Biophys Res Commun. 1991;178(3):913-20.
29. Corbett JA, McDaniel ML. The Use of Aminoguanidine, a Selective iNOS Inhibitor, to Evaluate the Role of Nitric Oxide in the Development of Autoimmune Diabetes. Methods. 1996;10(1):21-30.

30. Bedoya FJ, Solano F, Lucas M. N-monomethyl-arginine and nicotinamide prevent streptozotocin-induced double strand DNA break formation in pancreatic rat islets. Experientia. 1996;52(4):344-7.

31. Bahorun T, Trotin F, Pommery J, Vasseur J, Pinkas M. Antioxidant activities of Crataegus monogyna extracts. Planta Med. 1994;60(4):323-8. doi: 10.1055/s-2006-959493.

32. Bernatoniene J, Masteikova R, Majiene D, Savickas A, Kevelaitis E, Bernatoniene R, et al. Free radical-scavenging activities of Crataegus monogyna extracts. Medicina (Kaunas). 2008;44(9):706-12.

33. Ruiz-Rodriguez BM, de Ancos B, Sanchez-Moreno C, Fernandez-Ruiz V, Sanchez-Mata Mde C, Camara M, et al. Wild blackthorn (Prunus spinosa L.) and hawthorn (Crataegus monogyna Jacq.) fruits as valuable sources of antioxidants. Fruits. 2014;69(1):61-73. doi: 10.1051/ fruits/2013102.

34. Rezaei-Golmisheh A, Malekinejad H, Asri-Rezaei S, Farshid AA, Akbari P. Hawthorn ethanolic extracts with triterpenoids and flavonoids exert hepatoprotective effects and suppress the hypercholesterolemia-induced oxidative stress in rats. Iran J Basic Med Sci. 2015;18(7):691-9.

35. Pari L, Rajarajeswari N. Efficacy of coumarin on hepatic key enzymes of glucose metabolism in chemical induced type 2 diabetic rats. Chem Biol Interact. 2009;181(3):292-6. doi: 10.1016/j.cbi.2009.07.018.

36. Quine SD, Raghu PS. Effects of (-)-epicatechin, a flavonoid on lipid peroxidation and antioxidants in streptozotocininduced diabetic liver, kidney and heart. Pharmacol Rep. 2005;57(5):610-5. 